\title{
WOMEN WORKERS, MIGRATION AND FAMILY IN SARAWAK
}

HEW Cheng Sim 


\section{Contents}

List of illustrations

viii

List of tables

Preface

1 Introduction

Women, wage work and the household 3

Rural-urban migration 7

2 A methodological discussion

An anthropology of women 11

A feminist anthropology 12

Feminist ethnography 15

Positionality and the politics of representation 19

Conclusion 24

3 Doing fieldwork at home

Research methods 27

Problems and limitations 30

4 The socio-economic context of change

Who are the Bidayuh? 34

Rural Bidayuh economy 36

Customary land tenure system 36

State discourse on the shifting cultivation of padi 38

Cash-cropping and the education of children 40

Bidayuh women in rural agrarian society 41

Transformation of village life 43

Rural-urban migration and urbanisation in Sarawak 43 
vi Contents

5 To market, to market: rural-urban migration and becoming modern

The desire to be 'modern' 49

Economic necessity and migration 59

Decision making about migration: a comparison 62

City or country? 63

Remittances and rural-urban relations 65

Conclusion 67

6 Overqualified and underpaid: wage work in the personal services sector

Some experiences of women in this sector of employment 73

Women's and men's work in the village 76

7 Sex and salaries: single women migrants in the city

Courtship and marriage in the village 90

Bidayuh weddings - then and now 91

Biday h households in the village 92

Sexuality and young women migrants 93

Marriage partner selection 94

Rejection of marriage 96

Conclusion 97

8 Marriage, money and men: working mothers and their households

Paid work and life-course squeezes 98

Working wives and their husbands: marriage in the $1990 \mathrm{~s} 105$

Autonomy through wage work? 110

Conclusion 113

9 The hand that rocks the cradle leaves wage work:

Bidayuh housewives

The Bidayuh housewife: a Western bourgeois family ideal or economic pragmatism? 116

For the sake of the children's education 117

Domestic division of labour 123

Management of household finances 127

Conclusion 131 
10 Holding their own: four women and their stories

Making do, siretching limits 134

Submission and resistance 138

Dominated and dominant 141

From abused wife to modern woman 144

Conclusion 147

11 Conclusion

Notes

Bibliography

Index 